Tinjauan Pustaka

\title{
Indikasi dan Persiapan Hemodialis Pada Penyakit Ginjal Kronis
}

\author{
Radias Zasra1', Harnavi Harun², Syaiful Azmi³
}

\begin{abstract}
Abstrak
Penyakit Ginjal Kronik (PGK) adalah kelainan struktural atau fungsi yang terjadi lebih dari 3 bulan dan mempunyai implikasi terhadap kesehatan serta diklasifikasikan berdasarkan penyebab, laju flitrasi glomerulus (LFG) dan albuminuria. Komplikasi serius yang ditimbulkan PGK dapat berupa malnutrisi, kelebihan cairan, perdarahan, serositis, depresi, gangguan kognitif, neuropati perifer, infertilitas dan Infeksi. Untuk mencegah komplikasi tersebut, diperlukan indikasi dan waktu yang tepat untuk memulai terapi dialisis pada pasien PGK.
\end{abstract}

Kata kunci: Indikasi, Persiapan, Hemodialisis, Penyakit Ginjal Kronik

\begin{abstract}
Chronic Kidney Disease (CKD) is a structural or functional abnormality that occurs more than 3 months and has health implications and is classified based on causes, glomerular filtration rate (GFR) and albuminuria. Serious complications caused by CKD can include malnutrition, excess fluid, bleeding, serositis, depression, cognitive impairment, peripheral neuropathy, infertility and infection. To prevent these complications, it is necessary to indicate and the right time to start dialysis therapy in CKD patients.
\end{abstract}

Keywords:Indication, Preparation, Hemodialysis, Chronic Kidney Disease

Affiliasi penulis : 1.Program Studi Pendidikan Profesi Dokter Spesialis-1 IImu Penyakit Dalam FK Unand/RSUP M Djamil Padang, 2.Subbagian Ginjal Hipertensi Bagian IImu Penyakit Dalam FK Unand/RSUP M Djamil Padang,

Korespondensi : radiaszasra@gmail.com Telp: +6281363195152

\section{PENDAHULUAN}

Penyakit ginjal kronik adalah suatu proses patofisiologis dengan etiologi yang beragam, mengakibatkan penurunan fungsi ginjal yang progresif, dan pada umumnya berakhir dengan gagal ginjal. Selanjutnya gagal ginjal adalah suatu keadaan klinis yang ditandai dengan penurunan fungsi ginjal yang ireversibel, pada suatu derajat yang memerlukan terapi pengganti ginjal yang tetap, berupa dialisis atau transplantasi ginjal. ${ }^{1}$

Definisi penyakit ginjal kronik berdasarkan KDOQI adalah²

1. Kerusakan ginjal (renal damage) yang terjadi lebih dari 3 bulan, berupa kelainan struktural atau fungsional, dengan atau tanpa penurunan laju filtrasi glomerulus (LFG), dengan manifestasi :

a. Kelainan patologis

b. Terdapat tanda kelainan ginjal, termasuk kelainan dalam komposisi darah atau urin atau kelainan dalam tes pencitraan (imaging tests).

2. Laju filtrasi glomerulus (LFG) kurang dari 60 $\mathrm{ml} / \mathrm{menit} / 1,73 \mathrm{~m}^{2}$ selama 3 bulan, dengan atau tanpa kerusakan ginjal.

Klasifikasi penyakit ginjal kronik didasarkan atas dua hal yaitu, atas dasar derajat (stage) penyakit dan atas dasar diagnosis etiologi. Klasifikasi atas dasar derajat penyakit, dibuat atas dasar LFG, yang dihitung dengan mempergunakan rumus KockcroftGault sebagai berikut: 2

(140-umur) $\mathrm{x}$ berat badan

$\operatorname{LFG}\left(\mathrm{ml} / \mathrm{mnt} / 1,73 \mathrm{~m}^{2}\right)=$

72x Kreatinin Plasma

${ }^{*}$ ) pada perempuan dikalikan 0,85

Tabel 1. Klasifikasi Penyakit Ginjal Kronik atas dasar derajat Penyakit. ${ }^{2}$

\begin{tabular}{|c|c|c|}
\hline Derajat & Penjelasan & $\begin{array}{c}\text { LFG } \\
(\mathrm{ml} / \mathrm{mnt} / 1,73 \\
\mathrm{m}^{2}\end{array}$ \\
\hline 1 & $\begin{array}{c}\text { Kerusakan ginjal } \\
\text { dengan LFG normal } \\
\text { atau } \uparrow\end{array}$ & $\geq 90$ \\
\hline 2 & $\begin{array}{c}\text { Kerusakan ginjal } \\
\text { dengan LFG } \uparrow \text { ringan }\end{array}$ & $60-89$ \\
\hline 3 & $\begin{array}{c}\text { Kerusakan ginjal } \\
\text { dengan LFG } \uparrow \text { sedang }\end{array}$ & $30-59$ \\
\hline 4 & $\begin{array}{l}\text { Kerusakan ginjal } \\
\text { dengan LFG } \uparrow \text { berat }\end{array}$ & $15-29$ \\
\hline 5 & Gagal ginjal & $\begin{array}{c}<15 \text { atau } \\
\text { dialisis }\end{array}$ \\
\hline
\end{tabular}

Indikasi Hemodialisis Pada Penyakit Ginjal Kronis Kidney Disease Outcome Quality Initiative (KDOQI) merekomendasikan untuk mempertimbangkan manfaat dan risiko memulai terapi pengganti ginjal (TPG) pada pasien dengan perkiraan laju filtrasi glomerulus (eLFG) kurang dari 15 $\mathrm{mL} /$ menit/1,73 $\mathrm{m}^{2}$ (PGK tahap 5). Akan tetapi kemudian terdapat bukti -bukti penelitian baru bahwa tidak terdapat perbedaan hasil antara yang memulai dialisis dini dengan yang terlambat memulai dialisis. 
Oleh karena itu pada PGK tahap 5, inisiasi HD dilakukan apabila ada keadaan sebagai berikut ${ }^{2}$

1. Kelebihan (overload) cairan ekstraseluler yang sulit dikendalikan dan / atau hipertensi.

2. Hiperkalemia yang refrakter terhadap restriksi diit dan terapi farmakologis.

3. Asidosis metabolik yang refrakter terhadap pemberian terapi bikarbonat.

4. Hiperfosfatemia yang refrakter terhadap restriksi diit dan terapi pengikat fosfat.

5. Anemia yang refrakter terhadap pemberian eritropoietin dan besi.

6. Adanya penurunan kapasitas fungsional atau kualitas hidup tanpa penyebab yang jelas.

7. Penurunan berat badan atau malnutrisi, terutama apabila disertai gejala mual, muntah, atau adanya bukti lain gastroduodenitis.

8. Selain itu indikasi segera untuk dilakukanya hemodialisis adalah adanya gangguan neurologis (seperti neuropati, ensefalopati, gangguan psikiatri), pleuritis atau perikarditis yang tidak disebabkan oleh penyebab lain,serta diatesis hemoragik dengan pemanjangan waktu perdarahan.

\section{Persiapan Hemodialisis}

Persiapan pasien sebelum inisiasi tindakan Hemodialisis kronik memegang peranan penting dalam kelancaran proses HD serta memiliki pengaruh yang cukup besar terhadap luaran pasien. Berbagai persiapan sebaiknya dilakukan mulai dari persiapan akses vaskular yang memerlukan waktu yang cukup untuk maturasi sampai ke skrining calon pasien. ${ }^{3}$

\section{Persiapan Kondisi Fisik Pasien}

Hemoglobin

Kadar hemoglobin $(\mathrm{Hb})$ penting untuk persiapan hemodialisis. Keadaan anemia dapat memperberat keadaan pasien. Anemia pada penyakit ginjal kronik terutama disebabkan oleh penurunan relatif produksi eritropoietin yang tidak sesuai dengan derajat anemianya. Faktor lain yang berkontribusi terhadap anemia pada PGK antara lain defisiensi besi, pemendekan umur eritrosit, hiperparatiroid sekunder, dan infeksi-inflamasi. ${ }^{3}$

Pada PGK stadium 4 dan 5, komplikasi metabolik sering dijumpai. Anemia berat berperan dalam kejadian gagal ventrikel kiri, kejadian cerebrovaskular dan penurunan kualitas hidup. Beberapa penelitian menunjukan kadar hemoglobin normal dapat menyebabkan efek yang merugikan, sehingga target kadar hemoglobin pada pasien penyakti ginjal kronik yang akan menjalani hemodialisis adalah 6,8-7,5 mmol/l. ${ }^{4}$

Anemia menyebabkan peningkatan angka morbiditas, mortalitas, serta angka perawatan di Rumah sakit. Selain itu, anemia juga menurunkan kualitas hidup, menurunkan kapasitas hemodinamik sistemik dan fungsi jantung, meningkatkan kejadian pembesaran ventrikel kiri jantung serta menurunkan kemampuan kognitifdan seksual. Beberapa penelitian membuktikan hubungan erat antara anemia dan progresifitas penurunan fungsi ginjal. 3,4

Target $\mathrm{Hb}$ pada pasien $\mathrm{HD}$ yang mendapat terapi erythropoietin stimulating agent (ESA) adalah 10-12 g/dl. Indikasi terapi ESA bila $\mathrm{Hb}<10 \mathrm{~g} / \mathrm{dl}$ dan penyebab lain anemia sudah disingkirkan. Tranfusi darah pada pasien PGK sedapat mungkin dihindari, hanya diberikan pada keadaan khusus. Indikasi tranfusi darah adalah ${ }^{3,4}$

1. $\mathrm{Hb}<7 \mathrm{~g} / \mathrm{dl}$ dengan atau tanpa gejala anemia

2. $\mathrm{Hb}<8 \mathrm{~g} / \mathrm{dl}$ dengan gangguan kardiovaskular yang nyata

3. Perdarahan akut dengan gejala gangguan hemodinamik.

4. Pasien yang akan menjalani operasi

\section{Pemeriksaan Penyakit Infeksi}

Pasien hemodialisis berisiko untuk terinfeksi oleh bakteri karena daya tahan tubuh yang turun dan infeksi virus yang ditularkan melalui darah. Infeksi virus hepatitis $\mathrm{B}$ dan $\mathrm{C}$ akan menyebabkan sirosis hati dan meningkatkan morbiditas dan mortalitas pada pasien hemodialysis. ${ }^{5}$

Pasien hemodialisis cenderung mendapatkan tranfusi darah berulang, sehingga pasien yang menjalani hemodialisis rutin mempunyai risiko tinggi untuk terinfeksi virus hepatitis $B$, virus hepatitis $C$ dibandingkan populasi normal. ${ }^{5}$

Pemeriksaan serologi pada pasien hemodialisis ${ }^{5}$

1. Semua pasien harus di periksa HBV, HCV dan HIV sebelum memulai dialisis.

2. HbsAg, anti HCV antibody harus diperiksa setiap 3 bulan pada pasien yang negatif HbsAg dan anti HCV

3. Anti HIV antibody harus di cek setiap 6 bulan.

4. Pasien dengan infeksi HBV kronis membutuhkan pemeriksaan tes HbsAg setiap tahun.

5. Semua pasien hemodialisis dengan $\mathrm{HbsAg}$ negatif harus di vaksinasi hepatitis $B$.

6. Pasien yang positif $\mathrm{HbsAg}$, HbeAg dan HBV DNA harus di hemodialisis dengan mesin dan ruangan yang terpisah.

Persiapan pasien sebelum inisiasi tindakan hemodialisis kronik memegang peranan penting dalam kelancaran proses HD serta memiliki pengaruh yang cukup besar terhadap luaran pasien. Berbagai persiapan sebaiknya dilakukan mulai dari persiapan akses vaskular yang memerlukan waktu yang cukup untuk maturasi sampai ke skrining calon pasien. ${ }^{5}$

\section{Akses Vaskular}

Untuk menentukan jenis akses vaskular yang paling cocok, anamnesis dan pemeriksaan fisik pada arteri dan sistem kardiopulmonari harus dilakukan. ${ }^{5}$ Terdapat dua jenis akses vaskuler 6

a. Akses Vaskular permanen

Adalah akses yang dianjurkan dalam hemodialisis. Terdiri dari AV shunt/AV fistula/cimino dan graft. 


\section{b. Akses Vaskular Temporer}

Adalah akses yang digunakan bila akses permanen belum tersedia/bermasalah. Akses ini meliputi akses vena femoralis, akses jugularis interna, dan akses vena subklavia.

Pasien PGK yang akan menjalani HD sebaiknya dirujuk lebih awal ke konsultan ginjal hipertensi sehingga pasien memiliki waktu yang cukup untuk mendapat edukasi dan perencanaan dialisis yang baik termasuk waktu yang cukup untuk pemasangan dan maturasi akses vascular. ${ }^{5}$

Pilihan akses vaskular terbaik adalah fistula arteriovenosa karena masa hidupnya yang lama serta risiko komplikasi yang lebih rendah dibandingkan dengan graft arterio venosa dan kateter. Sampai saat ini fistula AV masih menjadi pilihan utama akses vaskular untuk hemodialisis karena risiko infeksi dan kematian yang lebih rendah. Namun angka kegagalan primer dari fistula AV masih cukup tinggi sehingga penggunaan kateter vena sentral tidak dapat dihindarkan 5

Sebuah systemic review yang dilakukan pada 62 penelitian kohort (586.337 subyek) untuk menilai hubungan antara jenis akses vaskular (fistula arteriovenous, graft arteriovenous, dan kateter vena sentral) dengan risiko kematian, infeksi dan kejadian kardiovaskular mayor. Dibandingkan dengan subyek yang memakai fistula, subyek yang menggunakan kateter memiliki risiko lebih tinggi untuk semua penyebab kematian dan kejadian kardiovaskular. Demikian pula, jika dibandingkan dengan subyek dan graft, pasien yang menggunakan kateter memiliki risiko lebih tinggi untuk kematian dan kejadian kardiovaskular. Dibandingkan dengan pasien dengan fistula, subyek dengan graft memiliki risiko lebih tinggi untuk semua penyebab kematian namun tidak ada perbedaan dalam risiko kejadian kardiovaskular. Dari studi ini dapat disimpulkan bahwa pasien yang menggunakan kateter untuk hemodialisis tampaknya memiliki risiko tertinggi untuk kematian, infeksi dan kejadian kardiovaskular dibandingkan dengan jenis akses vaskular lainnya, dan pasien dengan fistula digunakan memiliki risiko terendah. ${ }^{5}$

\section{EDUKASI}

Hemodialisis yang baik memerlukan persiapan yang baik. Edukasi yang diberikan tepat waktu dapat memperbaiki luaran pasien penyakit gagal ginjal tahap akhir dan menurunkan biaya pengobatan. Perencanaan dialisis meliputi penentuan waktu inisiasi dialisis yang tepat dan pemasangan akses vaskular yang siap digunakan saat dialisis dimulai. Persiapan dialisis sebaiknya dimulai saat pasien telah memasuki penyakit gagal ginjal stadium 4. Beberapa alasannya adalah sulitnya memprediksi kecepatan progresifitas penyakit ginjal, tingginya variabilitas dalam derajat penurunan fungsi ginjal pada saat gejala uremikum terjadi ataupun saat indikasi dialisis lainnya muncul, respon dan adaptasi masingmasing pasien berbeda terhadap kondisi gagal ginjalnya, serta keberhasilan pemasangan akses vaskular permanen yang bervariasi dan membutuhkan waktu sampai beberapa bulan. 6,7

Program edukasi pada penyakit gagal ginjal tahap akhir meliputi pemberian informasi mengenai penyakit ginjal, pengelolaan penyakit ginjal kronik sebelum dialisis dimulai (termasuk terapi farmakologis dan intervensi diit) serta pilihan terapi pengganti ginjal. $^{7}$

Persiapan terhadap kondisi gagal ginjal dilakukan dengan memberikan edukasi pada pasien PGK stadium 4 dengan $\mathrm{LFG}<30 \mathrm{ml} /$ menit/1,73 $\mathrm{m}^{2}$ tentang kondisi gagal ginjal dan pilihan terapi termasuk transplantasi, dialisis atau konservatif. Edukasi ini juga diberikan kepada anggota keluarga dan orang yang merawat. ${ }^{7}$

Prinsip yang dipegang dalam manajemen pre-dialisis adalah 'to protect and to preserve' mulai dari ketika pasien awal didiagnosis PGK. Sebab pasien penyakit ginjal kronik, dalam mengahadapi kemungkinan dialisis setelah diagnosa ditegakan, akan menimbulkan stress yang hebat, umumnya merasakan tidak berdaya dan tidak ada harapan. Secara umum konsep manajemen integrasi pelayanan pasien pre-dialisis dapat dilihat dalam Gambar 1.7

Sebuah uji klinis acak terkontrol terhadap 257 orang pasien penyakit gagal ginjal kronik predialisis untuk mengetahui manfaat intervensi psikoedukasional predialisis (IPP) di 15 unit nefrologi di Kanada. Sebanyak 149 pasien dirandomisasi untuk menerima IPP dan 148 pasien mendapatkan pengelolaan standar. Waktu memulai dialisis ditemukan lebih panjang secara bermakna pada kelompok yang mendapatkan IPPn. Pengetahuan yang diperoleh pasien menentukan waktu untuk terapi dialisis, dan pasien dalam kelompok IPP memperlihatkan pengetahuan yang lebih mendalam tentang penyakitnya. Pasien yang mempunyai mekanisme coping dengan menghindari informasi terkait ancaman (threat-related information/blunting) memiliki waktu untuk memulai dialisis yang lebih pendek pada kelompok yang mendapatkan pengelolaan standar sedangkan pada kelompok IPP waktu untuk memulai dialisis lebih panjang. ${ }^{8}$

Suatu studi kohort retrospektif disebuah senter di Korea dengan melibatkan 1218 pasien Penyakit Ginjal Kronik predialisis dan di follow-up selama 30 bulan. Studi ini memakai propensity score matching untuk menilai peranan edukasi multidisiplin predialisis (EMP) pada pasien PGK. Edukasi multidisiplin predialisis terbukti dapat mengurangi angka dialisis yang tidak terencana dan mengurangi lama perawatan di Rumah sakit. Resipien EMP memiliki status metabolik yang lebih baik saat inisiasi Terapi Pengganti Ginjal. Tidak ditemukan bukti angka harapan hidup yang lebih baik pada kelompok EMP namun resipien EMP memiliki insiden kejadian kardiovaskular yang lebih rendah. ${ }^{9}$ 


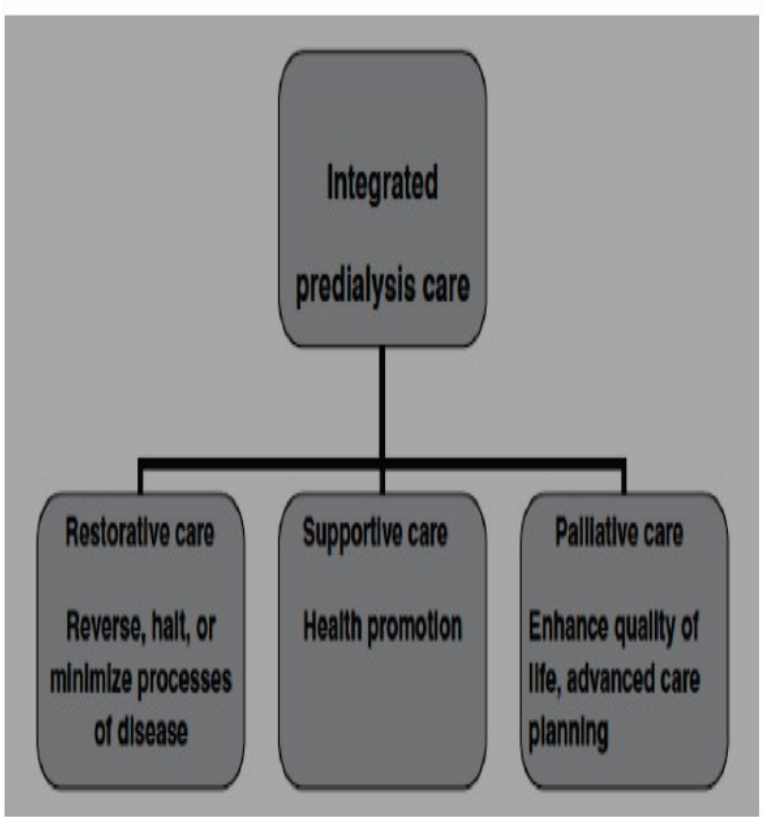

Gambar 1. Konsep manajemen integrasi pelayanan pre-dialisis. ${ }^{7}$

Luaran pasien predialisis yang dirujuk untuk menjalani program edukasi predialisis (PEP) $(n=93)$ dibandingkan dengan pasien yang menerima pengelolaan nefrologi standar $(n=52)$ dan pasien yang terlambat dirujuk ke ahli ginjal $(n=84)$. Studi ini menilai luaran pasien yang dirujuk ke 2 senter di Italia dalam periode 30 bulan. Sebanyak 229 pasien dengan median usia 70 tahun berpartisipasi dalam penelitian. Program edukasi predialisis terdiri dari merujuk pasien ke klinik yang memiliki ahli ginjal dan perawat yang melaksanakan program edukasi dan strategi tatalaksana yang direkomendasikan. Pasien yang menerima PEP secara bermakna memiliki angka inisiasi dialisis terencana yang lebih tinggi dan angka harapan hidup 1 tahun pasca inisiasi dialisis yang lebih baik dibandingkan dua kelompok lainnya. ${ }^{9}$

\section{SIMPULAN}

Indikasi dan Persiapan hemodialisis pada pasien PGK meliputi: persiapan kadar hemoglobin, pemeriksaan penyakit menular, akses vaskular dan edukasi.

\section{DAFTAR PUSTAKA}

1. National Kidney Foundation: K/DOQI Clinical Practice Guidelines and Clinical Practice Recomendations $2015 \quad$ Updates: Hemodialysis Adequacy, Peritoneal Dialysis Adequacy and Vaskular Access. Am J Kidney Dis 2015; 48(Suppl 1): S1-S322.

2. Rayner $H$, Imai $E$. Approach to renal replacement therapy. $4^{\text {th }} \mathrm{Ed} \mathrm{In}$ : Floege $\mathrm{J}$, Johnson RJ, Feehally J, editors. Comprehensive clinical nephrology. Missouri: Elsevier Saunders, 2010; p.1019-30

3. Kelly J, Stanley M, Harris D. The CARI Guidelines. Acceptance onto dialysis guidelines. Nephrology

(Carlton), 2005;10(suppl 4): S46-S60.

4. Rayner HC, Imai E. Approach to renal replacement therapy. $4^{\text {th }} \mathrm{Ed} \mathrm{In}$ : Floege $\mathrm{J}$, Johnson RJ, Feehally J, editors. Comprehensive clinical nephrology. Missouri: Elsevier Saunders, 2010; p.1019-30

5. Ravani P, Marinangeli G, Tancredi M, Malberti F. Mutidiciplinary chronic kidney disease management improves survival on dialysis. J Nephrol.2003; 16(6):870-7.

6. Stevens L, Stoycheff N, Levey A. Satging and mangement of chronic kidney disease. Greenberg: primer on kidney disease, $5^{\text {th }}$ edition. 2010.

7. Devins GM, Mendelssohn DC, Barre PE, Binik YM. Predialysis psychoeducational intervention and coping styles influence time to dialysis in chronic kidney disease. Am J Kidney Dis.2003;42(4):693-703.

8. Cho E, Park HC, Yoon HB, Ju KD, Kim H, Oh $\mathrm{YK}$, et al. Effect of multidisciplinary predialysis education in advanced chronic kidney disease: Prospensity score matcehd cohort analysis.Nephrology (Carlton) . 2012 Jul ; 17(5):472-9

9. Ravani $P$, Marinangeli G, Tancredi M, Malberti F. Mutidiciplinary chronic kidney disease management improves survival on dialysis. J Nephrol. 2003; 16(6):870-7. 